\title{
Eyes that cannot be seen: a rare case of ankyloblepharon filiforme adnatum (AFA) in a neonate
}

\author{
Nripen Gaur, ${ }^{1}$ Rachna Meel, ${ }^{2}$ Adarsh Shashni, ${ }^{2}$ Nawazish Shaikh ${ }^{1}$
}

${ }^{1}$ Department of Ophthalmology, Dr Rajendra Prasad Centre for Ophthalmic Sciences, All India Institute of Medical Sciences, New Delhi, Delhi, India ${ }^{2}$ Dr Rajendra Prasad Centre for Ophthalmic Sciences, All India Institute of Medical Sciences, New Delhi, Delhi, India

Correspondence to Dr Rachna Meel, dr.rachnameel@gmail.com

Accepted 14 February 2018
Check for updates

To cite: Gaur N, Meel R, Shashni A, et al. BMJ Case Rep Published Online First: [please include Day Month Year]. doi:10.1136/bcr-2018224557

\section{DESCRIPTION}

An infant aged 17 days was presented to our clinic with inability to open both eyes along with facial deformity. The vitals were found to be normal and no other systemic abnormality was recorded. On ocular examination, the child was found to have bilateral ankyloblepharon along with cleft lip and cleft palate. An urgent examination was done under general anaesthesia which revealed ankyloblepharon involving bilateral eye (figure 1A) barring a small area on the medial aspect of both eyelids. A probe was passed from the small opening on both sides which revealed no adhesions between the lids and the underlying ocular structures (figure 1B). The patient was diagnosed as having ankyloblepharon filiforme adnatum (AFA) and the lids were separated gently with the help of Westcott scissors. The bare lid margins (figure 1C) were apposed using continuous 8-0 Vicryl sutures. At the end of the surgery, there was a complete resolution of ankyloblepharon (figure 1D). The neonate was subsequently referred to the department of
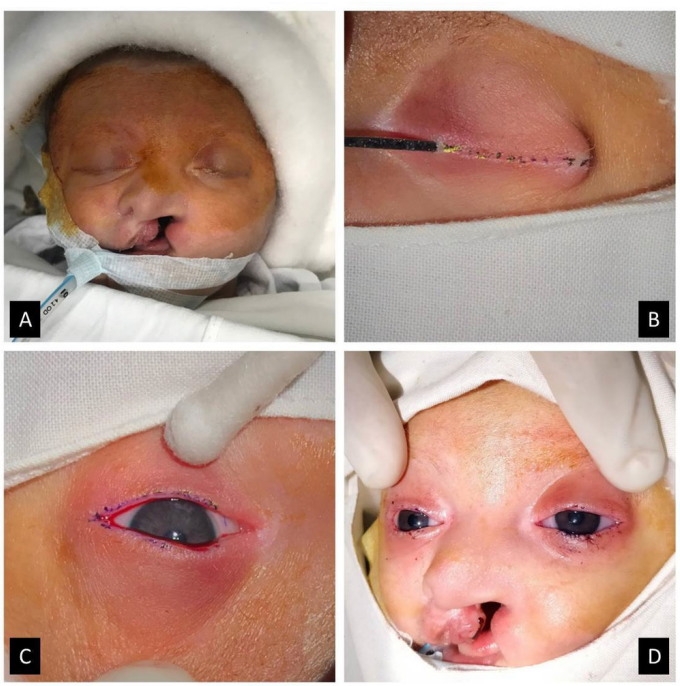

Figure 1 (A) Clinical photograph showing the presence of bilateral ankyloblepharon. (B) A probe being passed through the small opening in the lids to rule out any adhesion with underlying structures. (C) Raw lid margins after separation. (D) Postoperative clinical photograph. paediatric surgery for the correction of the facial defects.

AFA is a rare condition which involves the unison of the upper and the lower eyelids by a single or multiple bands of tissue ${ }^{1}$ which arise posterior to the cilia. ${ }^{2}$ This can occur as an isolated condition or as a part of syndrome. This condition is known to be associated with cleft palate and lip. Other associations that may be found include imperforate anus, meningocoele, infantile syndactyly, infantile glaucoma, and cardiac anomalies such as patent ductus arteriosus and ventricular septal defects. ${ }^{3}$ Hence, a comprehensive systemic examination must be performed to rule out such conditions. An early diagnosis and management can lead to prevention of a stimulus deprivation amblyopia which can have a devastating effect on the visual acuity of the neonate.

\section{Learning points}

Ankyloblepharon filiforme adnatum is a rare entity which can lead to serious visual impairment.

- An early identification and management can lead to good outcomes.

Contributors NG, AS and NS contributed to diagnosis, workup, writing the manuscript and performing critical revision. RM is the overall responsible for the presentation, contributed to diagnosis and performed critical revision of the manuscript.

Funding This research received no specific grant from any funding agency in the public, commercial or not-for-profit sectors.

Competing interests None declared.

Patient consent Parental/guardian consent obtained.

Provenance and peer review Not commissioned; externally peer reviewed.

(C) BMJ Publishing Group Ltd (unless otherwise stated in the text of the article) 2018. All rights reserved. No commercial use is permitted unless otherwise expressly granted.

\section{REFERENCES}

1 Ioannides A, Georgakarakos ND. Management of ankyloblepharon filiforme adnatum. Eye 2011:25:823.

2 Alami B, Maadane A, Sekhsoukh R. Ankyloblepharon filiforme adnatum: a case report. Pan Afr Med J 2013:15:15:15.

3 Gruener AM, Mehat MS. A newborn with ankyloblepharon filiforme adnatum: a case report. Cases J 2009:2:8146. 
Copyright 2018 BMJ Publishing Group. All rights reserved. For permission to reuse any of this content visit http://group.bmj.com/group/rights-licensing/permissions.

BMJ Case Report Fellows may re-use this article for personal use and teaching without any further permission.

Become a Fellow of BMJ Case Reports today and you can:

- Submit as many cases as you like

- Enjoy fast sympathetic peer review and rapid publication of accepted articles

Access all the published articles

- Re-use any of the published material for personal use and teaching without further permission

For information on Institutional Fellowships contact consortiasales@bmjgroup.com

Visit casereports.bmj.com for more articles like this and to become a Fellow 